Original Article

\title{
Phenotypic and molecular characterization of fluoroquinolone resistant Pseudomonas aeruginosa isolates in Palestine
}

\author{
Caracterização fenotípica e molecular de isolados de Pseudomonas aeruginosa \\ resistentes a fluoroquinolonas na Palestina
}

\author{
G. Adwan ${ }^{\mathrm{a} *}$ (1) and G. Omar ${ }^{\mathrm{a}}$ (1) \\ ${ }^{a}$ An-Najah National University, Department of Biology and Biotechnology, Nablus, Palestine
}

\begin{abstract}
Fluoroquinolones are important antimicrobial agents for the treatment of Pseudomonas infections. A total of 11 isolates of $P$. aeruginosa were collected from different clinical samples from different medical centers in the North West Bank-Palestine during 2017. In this study, resistance to fluoroquinolones and secretions of $\beta$-lactamases were detected by phenotypic methods, while presence of $\beta$-lactamase gene sequences and other virulence factors were detected by PCR technique. PCR product for gyrA, parC and parE genes were sequenced for further analyses. The phylogenetic analyses, population diversity indices and haplotypes determination were conducted using computer programs MEGA version 6, DnaSP 5.1001 and median-joining algorithm in the program Network 5, respectively. Results of this study showed that the MIC for ciprofloxacin and norfloxacin had a range of $32-256 \mu \mathrm{g} / \mathrm{ml}$. In addition, all isolates carried either exoT or exoT and exoY genes, different $\beta$-lactamase genes and $82 \%$ of these isolates harbored class 1 integrons. Analyses of the gyrA, parC and parE sequences were found to be polymorphic, had high haplotype diversity (0.945-0.982), low nucleotide diversity (0.01225-0.02001) and number of haplotypes were 9 for each gyrA and parE genes and 10 haplotypes for parC gene. The founder haplotypes being Hap-1 (18\%), Hap-2 (27.3\%) and Hap-6 (9.1\%) for gyrA, parC and parE genes, respectively. Two of ParE haplotypes were detected as indel haplotypes. The Median-joining- (MJ) networks constructed from haplotypes of these genes showed a star-like expansion. The neutrality tests (Tajima's D test and Fu's Fs test) for these genes showed negative values. Palestinian fluoroquinolone resistant $P$. aeruginosa strains showed high MIC level for fluoroquinolones, $\beta$-lactamase producers, carried type III secretion exotoxin-encoding genes, most of them had integrase I gene and had high level of mutations in QRDR regions in gyrA, parC and parE genes. All these factors may play an important role in the invasiveness of these strains and make them difficult to treat. Isolation of these strains from different medical centers, indicate the need for a strict application of infection control measures in Medical centers in the North West Bank-Palestine that aim to reduce expense and damage caused by P. aeruginosa infections. Molecular analyses showed that Palestinian fluoroquinolone resistant $P$. aeruginosa haplotypes are not genetically differentiated; however, more mutations may exist in these strains.
\end{abstract}

Keywords:P. aeruginosa, gyrA, parC, parE, haplotypes.

\section{Resumo}

Fluoroquinolonas são agentes antimicrobianos importantes para o tratamento de infecções por Pseudomonas. Um total de 11 bacilos isolados de P. aeruginosa foram coletados de diferentes amostras clínicas provenientes de diferentes centros médicos na Cisjordânia-Palestina durante o ano de 2017. Neste estudo, resistência a fluoroquinolonas e secreções de $\beta$-lactamases foram detectadas por métodos fenotípicos, enquanto a presença de sequências do gene $\beta$-lactamase e outros fatores de virulência foram detectados pela técnica de PCR (Proteína C-reativa). O produto de PCR para os genes gyrA, parC e parE foram sequenciados para análises posteriores. As análises filogenéticas, os índices de diversidade populacional e a determinação de haplótipos foram realizados utilizando os softwares MEGA versão 6, DnaSP 5.1001 e o algoritmo de junção de mediana do programa Network 5 , respectivamente. Os resultados deste estudo mostraram que a MIC para ciprofloxacina e norfloxacina tinha um intervalo de $32-256 \mu \mathrm{g} / \mathrm{ml}$. Além disso, todos os bacilos isolados carregavam genes exoT ou exoT e exoY, genes de $\beta$-lactamase diferentes e $82 \%$ desses isolados continham integrons de classe 1 . As análises das sequências gyrA, parC e parE foram consideradas polimórficas, com alta diversidade de haplótipos (0,945-0,982), baixa diversidade de nucleotídeos $(0,01225-0,02001)$ e o número de haplótipos foi de 9 para cada gene de gyrA e parE e 10 haplótipos para o gene parC. Os haplótipos fundadores são Hap-1 (18\%), Hap-2 (27,3\%) e Hap-6 (9,1\%) para os genes gyrA, parC e parE, respectivamente. Dois dos haplótipos parE foram detectados como haplótipos InDel. As redes Median-joining (MJ) construídas a partir de haplótipos desses genes mostraram uma expansão semelhante à de uma estrela. Os

*e-mail: adwang@najah.edu

Received: June 20, 2020 - Accepted: November 23, 2020

This is an Open Access article distributed under the terms of the Creative Commons Attribution License, which permits unrestricted use, distribution, and reproduction in any medium, provided the original work is properly cited. 
testes de neutralidade (teste D de Tajima e teste Fs de Fu) para esses genes apresentaram valores negativos. As cepas palestinas de $P$. aeruginosa resistentes a fluoroquinolonas mostraram alto nível de MIC para fluoroquinolonas, produtores de $\beta$-lactamase, genes codificadores de exotoxina de secreção tipo III, a maioria deles tinha o gene integrase I e tinha alto nível de mutações nas regiões QRDR nos genes gyrA, parC e parE. Todos esses fatores podem desempenhar um papel importante na invasão dessas cepas e torná-las difíceis de tratar. O isolamento dessas cepas em diferentes centros médicos, indica a necessidade de uma aplicação estrita de medidas de controle de infecção em centros médicos da Cisjordânia-Palestina que visam reduzir despesas e danos causados por infecções por $P$. aeruginosa. As análises moleculares mostraram que os haplótipos de $P$. aeruginosa resistentes à fluoroquinolona palestina não são geneticamente diferenciados; no entanto, mais mutações podem existir nessas cepas.

Palavras-chave:P. aeruginosa, gyrA, parC, parE, haplótipos.

\section{Introduction}

Pseudomonas aeruginosa is considered as one of the most important opportunistic Gram-negative pathogen that can cause many human infections including life-threatening (Lihua et al., 2013). Antibiotic resistance against this pathogen happens naturally as well as its ability to acquire resistance to a wide range of antimicrobial classes, make infections caused by this species of bacteria difficult to manage (Perez et al., 2014). The antipseudomonal agents are very limited and categorized into three major antimicrobial classes: lactams, aminoglycosides and fluoroquinolones (Giamarellou and Antoniadou, 2001). Fluoroquinolones such as levofloxacin and ciprofloxacin are considered as drugs of choice for treatment of $P$. aeruginosa infections (Llanes et al., 2011). These agents act by inhibiting the action of certain DNA replication enzymes such as DNA gyrase (type II topoisomerases) and topoisomerase IV (Dalhoff, 2012). DNA gyrase consists of an A2B2 heterotetramer encoded by the gyrA and gyrB genes, while topoisomerase IV exists as a C2E2 heterotetramer encoded by the parC and parE genes (Wydmuch et al., 2005).

It was reported that mutations in the DNA gyrase and topoisomerase IV (Agnello and Wong-Beringer, 2012; Kobayashi et al., 2013), efflux pump system overexpression and the innate impermeability of the membrane (Speciale et al., 2000; Teresa Tejedor et al., 2003) are mechanisms of fluoroquinolone resistance in P. aeruginosa. Sequence mutations in quinolone-resistance-determining region (QRDR) within DNA gyrase and topoisomerase IV are considered as major mechanism for fluoroquinolone resistance in P. aeruginosa (Nouri et al., 2016). Mutations in QRDR of DNA gyrase and topoisomerase IV, usually happen more frequently in gyrA and parC genes, respectively, and express the highest level of fluoroquinolone resistance. Mutation frequency in gyrB and parE genes is relatively low compared to that reported in gyrA and parC genes (Lee et al., 2005; Lister et al., 2009; Nouri et al., 2016).

This study aimed to determine the phenotypic and molecular characterization of clinical isolates of fluoroquinolone resistant $P$. aeruginosa. The current study designed to detect $\beta$-lactamases genes and their secretions, integrons 1, 2 and 3 and type III secretion system (T3SS) among clinical isolates of fluoroquinolone resistant $P$. aeruginosa. Additionally, It is designed to determine genetic diversity among these isolates depending on sequence analysis of gyrA, parE and parC genes. To our knowledge, this is the first study of its kind in Palestine and in many other countries around.

\section{Materials and Methods}

\subsection{Bacterial strains collection and identification}

A total of 11 isolates of $P$. aeruginosa were collected from different clinical samples during 2017. The samples included 2 urine, 6 wound swabs, 1 sputum trap and 2 ear swabs. The isolates were collected from different medical centers in the North West Bank-Palestine and identified by API 20NE system (Biomerieux) and identification was confirmed using conventional methods in microbiology research laboratory, at An-Najah National University. Replicate isolates from the same patient were excluded.

\subsection{Antibiotic resistant test}

Antimicrobial sensitivity testing was conducted according to instructions determined by the Clinical and Laboratory Standard Institute (CLSI, 2016) using the disk diffusion method. All P. aeruginosa isolates were examined using the following disks (Oxoid); Ciprofloxacin (CIP) $5 \mu \mathrm{g}$, Norfloxacin (NOR) $10 \mu \mathrm{g}$, Cefotaxime (CTX) 10 $\mu \mathrm{g}$, Ceftazidime (CAZ) $30 \mu \mathrm{g}$, Imipenem (IPM) $10 \mu \mathrm{g}$ and Meropenem (MEM) $10 \mu \mathrm{g}$. Mueller Hinton agar (MHA) (Oxoid) plates were seeded with McFarland 0.5 standard of $P$. aeruginosa strains, antibiotic disks were placed on the seeded plates. Then, the plates were incubated at $37^{\circ} \mathrm{C}$ for $24 \mathrm{~h}$. The inhibition zones were measured, and the isolates were classified as resistant or susceptible according to the criteria recommended by CLSI guidelines (CLSI, 2016). Isolates showed resistance to $3^{\text {rd }}$ generation cephalosporins were tested for the production of ESBLs and AmpC $\beta$-lactamases, and those showed resistance to carbapenems were tested for the secretion of MBLs. The minimum inhibitory concentration (MIC) values for Ciprofloxacin and Norfloxacin were also determined by broth microdilution method following CLSI guidelines and breakpoints (CLSI, 2016). The reference strain of P. aeruginosa ATCC 27853 was used as a quality control in all of the experiments of antimicrobial susceptibility testing.

\subsection{Detection of $\beta$-lactamases production by phenotypic tests}

$P$. aeruginosa isolates that showed resistance to $3^{\text {rd }}$ generation cephalosporins were tested for the production of extended spectrum $\beta$-lactamases (ESBLs) and AmpC $\beta$-lactamases by combination double disk test (CDDT) and combined disk method, respectively, as described previously (Ibrahim et al., 2013; Mansouri et al., 2014). Isolates showed resistance to carbapenems were tested 
for the secretion of Metallo- $\beta$-lactamases (MBLs) using two different tests, combined disc diffusion test (CDDT) as described previously (Yong et al., 2002; Franklin et al., 2006) and double disc synergy test (DDST) as described previously by Lee et al. (2003)

\subsection{DNA extraction}

$P$. aeruginosa genome was prepared for PCR according to the method described previously (Adwan et al., 2013). Briefly, the cells were scraped off an overnight MHA plate, washed with $800 \mu \mathrm{L}$ of $1 \mathrm{X}$ Tris-EDTA buffer (10 mM Tris$\mathrm{HCl}, 1 \mathrm{mM}$ EDTA [pH 8]), centrifuged, and the pellet was resuspended in $400 \mu \mathrm{L}$ of sterile double distilled $\mathrm{H}_{2} \mathrm{O}$, and boiled for $10-15 \mathrm{~min}$. The cells were incubated on ice for ten minutes. The debris were pelleted by centrifugation at $11,500 \mathrm{X} \mathrm{g}$ for $5 \mathrm{~min}$. The DNA concentration was determined using a nanodrop spectrophotometer (Genova Nano, Jenway). The DNA samples were stored at $-20^{\circ} \mathrm{C}$ for further analyses.

\subsection{Detection of antibiotic resistance genes}

The presence of AmpC $\beta$-lactamase (Class $C$ ) genes, extended spectrum $\beta$-lactamases (Class A and D) genes and Metallo- $\beta$-lactamases (Class B) genes was investigated using multiplex PCR divided into pool 1, pool 2 and pool 3, respectively. The sequence of primers, amplicon sizes and annealing temperatures are listed in Table 1.

Table 1. Target genes for PCR amplification, fragment size and primer sequences that were used in this study.

\begin{tabular}{|c|c|c|c|c|c|}
\hline Group & Targets & Primer sequence $5^{\prime} \rightarrow \mathbf{3}^{\prime}$ & 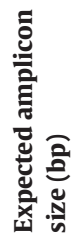 & 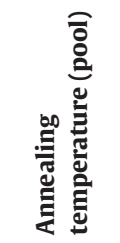 & References \\
\hline \multirow{12}{*}{$\begin{array}{c}\text { AmpC } \\
\beta \text {-lactamase } \\
(\text { Class C) }\end{array}$} & \multirow{2}{*}{$\begin{array}{c}M O X-1, M O X-2 \\
C M Y-1, C M Y-8 \text { to } \\
\text { CMY-11 }\end{array}$} & MOXM F GCT GCT CAA GGA GCA CAG GAT & \multirow[t]{2}{*}{520} & \multirow[t]{2}{*}{$64{ }^{\circ} \mathrm{C}(1)$} & \multirow{2}{*}{$\begin{array}{c}\text { Pérez-Pérez and } \\
\text { Hanson (2002) }\end{array}$} \\
\hline & & MOXM R CAC ATT GAC ATA GGT GTG GTG C & & & \\
\hline & \multirow{2}{*}{$\begin{array}{c}L A T-1 \text { to } L A T-4, \\
\text { CMY-2 to CMY-7, } \\
\text { BIL-1 }\end{array}$} & CITM F TGG CCA GAA CTG ACA GGC AAA & \multirow[t]{2}{*}{462} & \multirow[t]{2}{*}{$64{ }^{\circ} \mathrm{C}(1)$} & \multirow{2}{*}{$\begin{array}{l}\text { Pérez-Pérez and } \\
\text { Hanson (2002) }\end{array}$} \\
\hline & & CITM R TTT CTC CTG AAC GTG GCT GGC & & & \\
\hline & \multirow[t]{2}{*}{$D H A-1, D H A-2$} & DHAM F AAC TTT CAC AGG TGT GCT GGG T & \multirow[t]{2}{*}{405} & \multirow[t]{2}{*}{$64{ }^{\circ} \mathrm{C}(1)$} & \multirow{2}{*}{$\begin{array}{c}\text { Pérez-Pérez and } \\
\text { Hanson (2002) }\end{array}$} \\
\hline & & DHAM R CCG TAC GCA TAC TGG CTT TGC & & & \\
\hline & \multirow[t]{2}{*}{$A C C$} & ACCM F AAC AGC CTC AGC AGC CGG TTA & \multirow[t]{2}{*}{346} & \multirow[t]{2}{*}{$64{ }^{\circ} \mathrm{C}(1)$} & \multirow{2}{*}{$\begin{array}{c}\text { Pérez-Pérez and } \\
\text { Hanson (2002) }\end{array}$} \\
\hline & & ACCM R TTC GCC GCA ATC ATC CCT AGC & & & \\
\hline & \multirow[t]{2}{*}{$M I R-1 T, A C T-1$} & EBCM F TCG GTA AAG CCG ATG TTG CGG & \multirow[t]{2}{*}{302} & \multirow[t]{2}{*}{$64{ }^{\circ} \mathrm{C}(1)$} & \multirow{2}{*}{$\begin{array}{c}\text { Pérez-Pérez and } \\
\text { Hanson (2002) }\end{array}$} \\
\hline & & EBCM R CTT CCA CTG CGG CTG CCA GTT & & & \\
\hline & \multirow[t]{2}{*}{ FOX-1 to FOX-5b } & FOXM F AAC ATG GGG TAT CAG GGA GAT G & \multirow[t]{2}{*}{190} & \multirow[t]{2}{*}{$64{ }^{\circ} \mathrm{C}(1)$} & \multirow{2}{*}{$\begin{array}{l}\text { Pérez-Pérez and } \\
\text { Hanson (2002) }\end{array}$} \\
\hline & & FOXM R CAA AGC GCG TAA CCG GAT TGG & & & \\
\hline \multirow{8}{*}{$\begin{array}{c}\text { extended } \\
\text { spectrum } \\
\beta \text {-lactamases } \\
\text { (Class A) }\end{array}$} & \multirow[t]{2}{*}{ SHV } & SHV F ATG CGT TATATT CGC CTG TG & \multirow[t]{2}{*}{747} & \multirow[t]{2}{*}{$60^{\circ} \mathrm{C}(2)$} & \multirow{2}{*}{$\begin{array}{l}\text { Paterson et al. } \\
\qquad(2003)\end{array}$} \\
\hline & & SHV R TGC TTT GTT ATT CGG GCC AA & & & \\
\hline & \multirow[t]{2}{*}{ TEM } & $\begin{array}{l}\text { TEM F TCG CCG CAT ACA CTA TTC TCA GAA } \\
\text { TGA }\end{array}$ & \multirow[t]{2}{*}{445} & \multirow[t]{2}{*}{$60^{\circ} \mathrm{C}(2)$} & \multirow[t]{2}{*}{$\begin{array}{l}\text { Monstein et al. } \\
\text { (2007) }\end{array}$} \\
\hline & & TEM R ACG CTC ACC GGC TCC AGA TTT AT & & & \\
\hline & \multirow[t]{2}{*}{$C T X$} & $\begin{array}{l}\text { CTX-M F ATG TGC AGY ACC AGT AAR GTK } \\
\text { ATG GC }\end{array}$ & 593 & $60{ }^{\circ} \mathrm{C}(2)$ & $\begin{array}{l}\text { Boyd et al. } \\
\text { (2004) }\end{array}$ \\
\hline & & $\begin{array}{l}\text { CTX-M R TGG GTR AAR TAR GTS ACC AGA } \\
\text { AYC AGC GG }\end{array}$ & & & \\
\hline & $\mathrm{KPC}$ & КPCM F CGTCTAGTTCTGCTGTCTTG & 789 & $60{ }^{\circ} \mathrm{C}(2)$ & Poirel et al. \\
\hline & & KPCM R CTTGTCATCCTTGTTAGGCG & & & $(2011)$ \\
\hline extended & $O X A$ & OXA F 5-ATT ATC TAC AGC AGC GCC AGT G-3 & 296 & $60^{\circ} \mathrm{C}(2)$ & Kim et al. (2009) \\
\hline $\begin{array}{c}\text { spectrum } \\
\beta \text {-lactamases } \\
\text { (Class D) }\end{array}$ & & OXA R 5-TGC ATC CAC GTC TTT GGT G-3 & & & \\
\hline
\end{tabular}


Table 1. Continued...

\begin{tabular}{|c|c|c|c|c|c|}
\hline Group & Targets & Primer sequence $5^{\prime} \rightarrow 3^{\prime}$ & 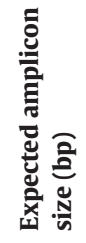 & 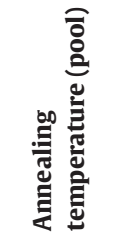 & References \\
\hline \multirow{10}{*}{$\begin{array}{c}\text { Metallo- } \beta \text { - } \\
\text { lactamases } \\
\text { (Class B) }\end{array}$} & \multirow[t]{2}{*}{$\operatorname{Imp}$} & Imp-F 5-GGAATAGAGTGGCTTAAYTCTC-3 & \multirow[t]{2}{*}{ 188bp } & \multirow[t]{2}{*}{$52 \stackrel{\circ}{ } \mathrm{C}(3)$} & \multirow{2}{*}{$\begin{array}{c}\text { Ellington et al. } \\
\text { (2007) }\end{array}$} \\
\hline & & Imp-R 5-CCAAACYACTASGTTATCT-3 & & & \\
\hline & \multirow[t]{2}{*}{ Vim } & Vim-F 5-GATGGTGTTTGGTCGCATA-3 & \multirow[t]{2}{*}{ 390bp } & \multirow[t]{2}{*}{$52 \stackrel{\circ}{ } \mathrm{C}(3)$} & \multirow{2}{*}{$\begin{array}{c}\text { Ellington et al. } \\
(2007)\end{array}$} \\
\hline & & Vim-R 5-CGAATGCGCAGCACCAG-3 & & & \\
\hline & \multirow[t]{2}{*}{ Gim } & Gim-F 5-TCGACACACCTTGGTCTGAA-3 & \multirow[t]{2}{*}{ 477bp } & \multirow[t]{2}{*}{$52^{\circ} \mathrm{C}(3)$} & \multirow{2}{*}{$\begin{array}{c}\text { Ellington et al. } \\
\text { (2007) }\end{array}$} \\
\hline & & Gim-R 5-AACTTCCAACTTTGCCATGC-3 & & & \\
\hline & \multirow[t]{2}{*}{ Spm } & Spm-F 5-AAAATCTGGGTACGCAAACG-3 & \multirow[t]{2}{*}{$271 \mathrm{bp}$} & \multirow[t]{2}{*}{$52 \stackrel{\circ}{ } \mathrm{C}(3)$} & \multirow{2}{*}{$\begin{array}{l}\text { Ellington et al. } \\
\text { (2007) }\end{array}$} \\
\hline & & Spm-R 5-ACATTATCCGCTGGAACAGG-3 & & & \\
\hline & \multirow[t]{2}{*}{ Sim } & Sim-F 5-TACAAGGGATTCGGCATCG-3 & \multirow[t]{2}{*}{ 570bp } & \multirow[t]{2}{*}{$52{ }^{\circ} \mathrm{C}(3)$} & \multirow{2}{*}{$\begin{array}{c}\text { Ellington et al. } \\
\text { (2007) }\end{array}$} \\
\hline & & Sim-R 5-TAATGGCCTGTTCCCATGTG-3 & & & \\
\hline \multirow[t]{6}{*}{ Integrases } & \multirow[t]{2}{*}{ intI1 } & intI1 F 5-GCATCCTCGGTTTTCTGG-3 & \multirow[t]{2}{*}{ 457bp } & \multirow[t]{2}{*}{$58{ }^{\circ} \mathrm{C}(4)$} & \multirow{2}{*}{$\begin{array}{c}\text { Shibata et al. } \\
\text { (2003) }\end{array}$} \\
\hline & & intI1 R 5-GGTGTGGCGGGCTTCGTG-3 & & & \\
\hline & \multirow[t]{2}{*}{ intI2 } & intI2 F 5-CACGGATATGCGACAAAAAGG T-3 & \multirow[t]{2}{*}{ 789bp } & \multirow[t]{2}{*}{$58^{\circ} \mathrm{C}(4)$} & \multirow{2}{*}{$\begin{array}{c}\text { Shibata et al. } \\
\text { (2003) }\end{array}$} \\
\hline & & intI2 R 5-GTAGCAAACGAGTGACGAAATG-3 & & & \\
\hline & \multirow[t]{2}{*}{ int I3 } & intI3 F 5-AT TGCCAAACCTGACTG-3 & $922 b p$ & $58^{\circ} \mathrm{C}(4)$ & Shibata et al. \\
\hline & & intI3 R 5-CGAATGCCCCAACAACTC-3 & & & (2003) \\
\hline type III & exos & Exo S F: GCG AGG TCA GCA GAG TAT CG & 118 & $56^{\circ} \mathrm{C}(5)$ & Ajayi et al. \\
\hline $\begin{array}{c}\text { secretion } \\
\text { system (T3SS) }\end{array}$ & & Exo S R: TTC GGC GTC ACT GTG GAT GC & & & (2003) \\
\hline & exoT & Exo T F: AAT CGC CGT CCA ACT GCA TGC G & 152 & $56^{\circ} \mathrm{C}(5)$ & Ajayi et al. \\
\hline & & Exo T R: TGT TCG CCG AGG TAC TGC TC & & & (2003) \\
\hline & exoU & Exo U F: CCG TTG TGG TGC CGT TGA AG & 134 & $56^{\circ} \mathrm{C}(5)$ & Ajayi et al. \\
\hline & & Exo U R: CCA GAT GTT CAC CGA CTC GC & & & $(2003)$ \\
\hline & exoY & Exo Y F: CGG ATT CTA TGG CAG GGA GG & 289 & $56^{\circ} \mathrm{C}(5)$ & Ajayi et al. \\
\hline & & Exo Y R: GCC CTT GAT GCA CTC GAC CA & & & (2003) \\
\hline Fluoroquinolone & GyrA & $\begin{array}{l}\text { GyrA F: TTA TGC CAT GAG CGA GCT GGG } \\
\text { CAA CGA CT }\end{array}$ & 366 & $65^{\circ} \mathrm{C}$ & $\begin{array}{l}\text { Sekiguchi et al. } \\
\text { (2005) }\end{array}$ \\
\hline & & $\begin{array}{l}\text { GyrA R: AAC CGT TGA CCA GCA GGT TGG } \\
\text { GAA TCT T }\end{array}$ & & & \\
\hline & ParC & ParC F: ATG AGC GAA CTG GGG CTG GAT & 210 & $58^{\circ} \mathrm{C}$ & Sekiguchi et al. \\
\hline & & ParC R: ATG GCG GCG AAG GAC TTG GGA & & & (2005) \\
\hline & ParE & $\begin{array}{l}\text { ParE F: CGG CGT TCG TCT CGG GCG TGG } \\
\text { TGA AGG A }\end{array}$ & 592 & $68^{\circ} \mathrm{C}$ & $\begin{array}{l}\text { Sekiguchi et al. } \\
\text { (2005) }\end{array}$ \\
\hline & & $\begin{array}{l}\text { ParE R: TCG AGG GCG TAG TAG ATG TCC } \\
\text { TTG CCG A }\end{array}$ & & & \\
\hline
\end{tabular}

\subsection{Detection of class 1, 2 and 3 integrons}

The detection of integrons intI1, intI2 and intI3 was carried out using multiplex PCR (see Table 1, pool 4). Primer sequences, the size of amplicons and annealing temperature are presented in Table 1.

\subsection{Detection of type III secretion exotoxin-encoding} genes

The detection of type III secretion exotoxin-encoding genes (exoS, exoT, exoU and exoY genes) was performed using multiplex PCR (see Table 1, pool 5). The Primer 
sequences, the size of amplicons and annealing temperature are shown in Table 1.

\subsection{Detection of quinolone resistance-determining regions (QRDRs) and DNA Sequencing}

The detection of quinolone resistance-determining regions (QRDRs) (gyrA, parC, and parE) of $P$. aeruginosa was performed using PCR. Primer sequences, the size of amplicons and annealing temperature are presented in Table 1. PCR products were analyzed by electrophoresis through $1.5 \%$ agarose gel. The amplified PCR products were purified by Wizard ${ }^{\circledR}$ SV Gel and PCR Clean-Up System (Promega) and sequenced using both forward and reverse primers by the dideoxy chain termination method (ABI PRISM sequencer, model 3130 Hitachi Ltd, Tokyo, Japan), at Bethlehem University, Bethlehem, Palestine. DNA sequence information was further submitted for accession numbers in GenBank.

\subsection{Bioinformatics analyses}

Continuous sequences were compared with previously available sequences of the gyrA, parC, and parE of $P$. aeruginosa in the National Center for Biotechnology Information (NCBI) using BLAST system. Multiple alignments were conducted using ClustalW of the computer program MEGA version 6 (Tamura et al., 2013). Phylogenetic analyses were based on alignments obtained from ClustalW of gyrA (365-bp), parC (209-bp) and parE (592-bp) sequences. Phylogenetic trees were constructed using the program Maximum Likelihood method in the same software. The robustness of the groupings in the Neighbor Joining analysis was assessed with 1000 bootstrap resamplings. The population diversity indices such as numbers of haplotype (h), haplotype diversity (Hd), nucleotide diversity ( $\pi$ ), and the neutrality indices including (Tajima's D and Fu's
Fs test) were calculated using DnaSP 5.1001 (Librado and Rozas 2009). Median-joining-(MJ) network of haplotypes of the gyrA, parC, and parE sequences of $P$. aeruginosa were analyzed using a median-joining algorithm in the program Network 5 (Bandelt et al. 1999). The gyrA, parC, and parE DNA sequences were numbered according to the reference sequences CP034434.1, CP025055.1 and CP021775.1, respectively, While the product of gyrA, parC, and parE sequences were numbered according to the reference sequences ANT75468.1, AUA79862.1 and ASA18488.1, respectively.

\section{Results}

\subsection{Antibiotic resistance and other virulence genes}

Results of the current study showed that all tested isolates were resistant to all tested antibiotics. The MIC for ciprofloxacin and norfloxacin had a range of $32-256 \mu \mathrm{g} / \mathrm{mL}$. In addition, all of the investigated isolates carried either exoT or exoT and exoY genes. In addition, these isolates phenotypically were $\beta$-lactamase producers and all of them carried different $\beta$-lactamase genes. A total of 9 of $P$. aeruginosa isolates (82\%) harbored class 1 integrons, while other classes were not detected (as shown in Table 2)

\subsection{Bioinformatics and DNA analyses}

The gyrA, parC and parE genes were amplified from all extracted DNA samples. The amplified products had 365-bp, 209-bp and 592-bp length for gyrA, parC and parE, respectively, were successfully sequenced and analyzed. The sequences were deposited in GenBank database under the accession numbers (MN064784-MN064794), and (MN067984- MN067994) and (MN067995-MN068005)

Table 2. Distribution of virulence genes and phenotypic characteristics among 11 fluoroquinolone resistant $P$. aeruginosa isolated in Palestine.

\begin{tabular}{|c|c|c|c|c|c|c|c|c|c|c|}
\hline & & & virt & ence $g$ & nes** & & & & tibiotic resista & \\
\hline Iso & ate No. Source & Jut & TCDI & MPI & A.m $\mathrm{C}$ & $\begin{array}{c}\text { Type III } \\
\text { secretion }\end{array}$ & CID $>$ & NOR & MIC for CIP & MIC for NOR \\
\hline 1 & Wound swab & Int1 & $\mathrm{N}$ & $\mathrm{P}$ & $\mathrm{P}$ & exoT, exoY & $\mathrm{R}$ & $\mathrm{R}$ & 32 & 64 \\
\hline 2 & Wound swab & Int1 & $\mathrm{P}$ & $\mathrm{P}$ & $\mathrm{N}$ & exoT, exoY & $\mathrm{R}$ & $\mathrm{R}$ & 64 & 64 \\
\hline 3 & Wound swab & Int1 & $\mathrm{N}$ & $\mathrm{P}$ & $\mathrm{N}$ & exoT, exoY & $\mathrm{R}$ & $\mathrm{R}$ & 32 & 128 \\
\hline 4 & Wound swab & Int1 & $\mathrm{N}$ & $\mathrm{P}$ & $\mathrm{P}$ & exoT, exoY & $\mathrm{R}$ & $\mathrm{R}$ & 32 & 128 \\
\hline 5 & Wound swab & Int1 & $\mathrm{N}$ & $\mathrm{P}$ & $\mathrm{P}$ & exoT & $\mathrm{R}$ & $\mathrm{R}$ & 64 & 32 \\
\hline 6 & Wound swab & Int1 & $\mathrm{P}$ & $\mathrm{P}$ & $\mathrm{P}$ & exoT & $\mathrm{R}$ & $\mathrm{R}$ & 128 & 128 \\
\hline 7 & Urine & $\mathrm{N}$ & $\mathrm{N}$ & $\mathrm{P}$ & $\mathrm{P}$ & exoT, exoY & $\mathrm{R}$ & $\mathrm{R}$ & 128 & 64 \\
\hline 8 & urine & Int1 & $\mathrm{N}$ & $\mathrm{P}$ & $\mathrm{P}$ & exoT, ехоY & $\mathrm{R}$ & $\mathrm{R}$ & 128 & 64 \\
\hline 9 & Ear swab & Int1 & $\mathrm{N}$ & $\mathrm{N}$ & $\mathrm{P}$ & exoT, exoY & $\mathrm{R}$ & $\mathrm{R}$ & 64 & 128 \\
\hline 10 & Ear swab & Int & $\mathrm{N}$ & $\mathrm{P}$ & $\mathrm{N}$ & exoT, exoY & $\mathrm{R}$ & $\mathrm{R}$ & 128 & 64 \\
\hline 11 & Sputum trap & $\mathrm{N}$ & $\mathrm{P}$ & $P$ & $\mathrm{~N}$ & exoT, exoY & $\mathrm{R}$ & $\mathrm{R}$ & 256 & 256 \\
\hline
\end{tabular}

* CIP: Ciprofloxacin; NOR: Norfloxacin; R: Resistant; S: Sensitive; ** P: positive; N: Negative 
for gyrA, parC and parE genes, respectively. Comparing the gyrA, parE and parC nucleotide sequences obtained from the $P$. aeruginosa strains isolated from Palestine with reference strains retrieved from GenBank confirmed that all these genes belonged to the species $P$. aeruginosa (as shown in Figure 1A, 1B and 1C).

To understand the genetic diversity of fluoroquinolone resistant $P$. aeruginosa in Palestine. Analyses of nucleotide sequences for gyrA, parC and parE genes were carried out using different softwares. Results of analyses showed that 9 haplotypes were detected for each gyrA and parC sequences, while 10 haplotyoes were detected for parE sequences. The founder haplotypes being Hap-1 (2 out of 11 isolates, 18\%), Hap-2 ( 3 out 11, 27.3\%) and Hap-6 (1 out 11, 9.1\%) for gyrA, parC and parE genes, respectively. Two of ParE haplotypes (Hap-9 and Hap-10) were indel haplotypes (as shown in Figure 2A, 2B and 2C and Table 3). The black nodes (Hap) are the DNA sequences for these genes which represent the haplotypes, while light black nodes are median vectors ( $\mathrm{mv}$ ), which are considered the hypothesized (often ancestral) sequences for our sequences (Figure 2A, 2B and 2C). additionally, this study showed that number of parsimony informative sites were 8,2 and 15 , while number of singleton variable sites were 8, 16 and 7 for gyrA, parC and parE gene, respectively (as shown in Figure 3 and Table 4 ). Amino acid alteration in these genes are presented in Figure 4.

The haplotype diversity (Hd) was $0.964,0.945$ and 0.982 , while the nucleotide diversity was $0.01225,0.02001$ and 0.01346 for gyrA, parC and parE genes, respectively (Table 4). The MJ networks constructed from haplotypes of gyrA, parC and parE sequences showed a star-like expansion with a major central Hap-1, Hap-2 and Hap-6 haplotype, respectively. The numbers of mutational steps between the major central haplotype and the others ranged from 1 to 7 for GyrA gene, 2 to 6 for ParC gene and 1 to 15 ParE gene (as shown in Figure 2). Low levels of polymorphism were detected in the both GyrA and ParC genes comparing to parE gene. Overall, there were 18, 22 and 31 point mutations between the major central haplotype and the other haplotypes for GyrA, ParC and parE genes (as shown in Figure 2). The neutrality tests (Tajima's D test and Fu's Fs test) for these genes showed negative values (see Table 4).
A

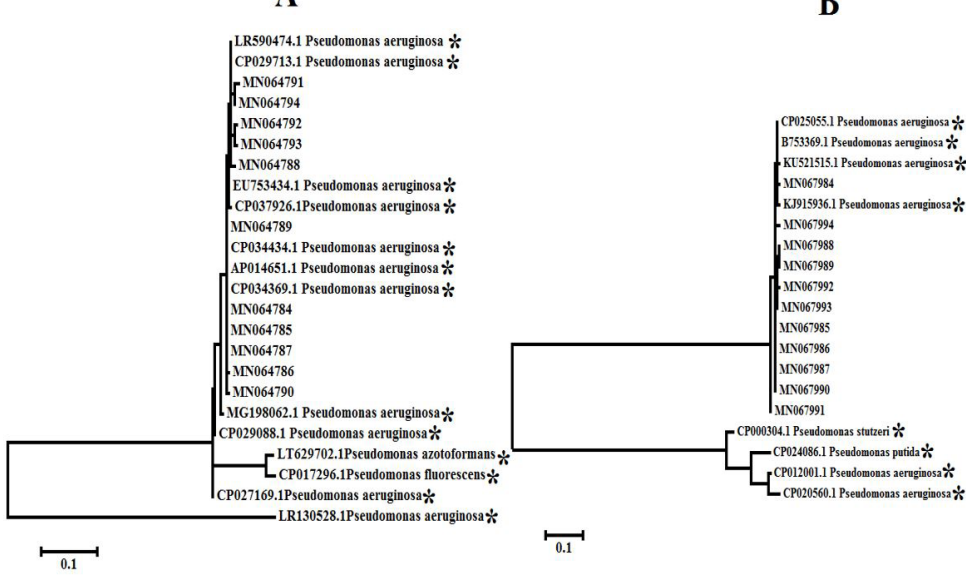

$\mathrm{C}$

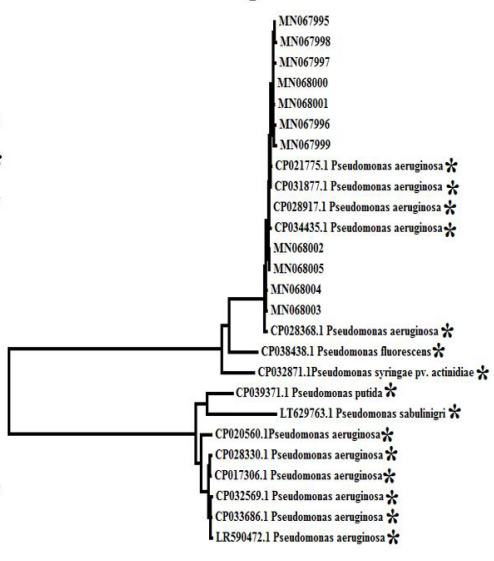

Figure 1. Molecular phylogenetic analysis by Maximum Likelihood method based on the GyrA (A), ParC (B) and ParE (C) sequence from fluoroquinolone resistant $P$. aeruginosa isolated in Palestine. Reference sequences retrieved from Genbank for the GyrA (A), ParC (B) and ParE (C) genes were denoted by asterisks $\left({ }^{*}\right)$. Sequences from Palestine and reference sequences were used to construct the phylogenetic tree. Evolutionary analyses were conducted in MEGA6.
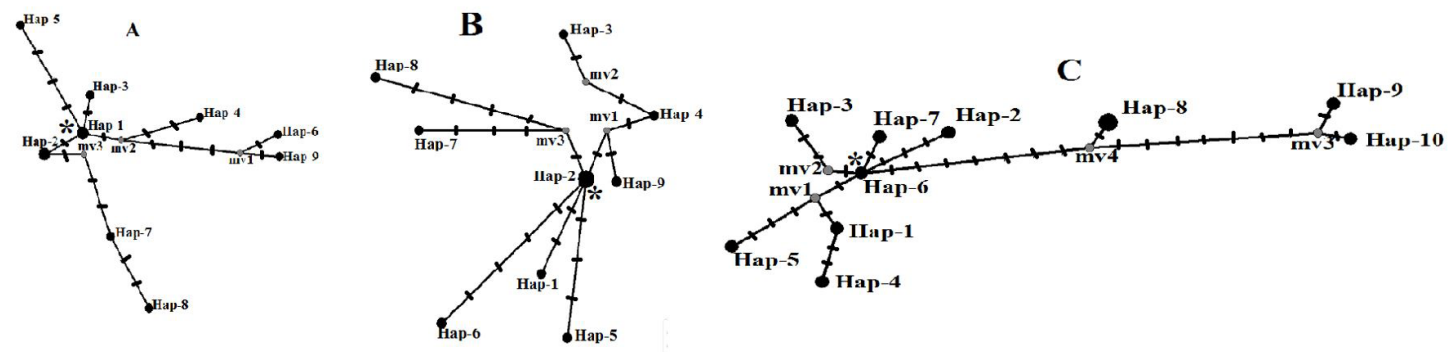

Figure 2. Median-joining network of $G y r A(A), \operatorname{ParC}(\mathrm{B})$ and $\operatorname{ParE}(\mathrm{C})$ of the haplotypes of fluoroquinolone resistant $P$. aeruginosa isolates. Each haplotype is represented by a circle. The asterisk $\left(^{*}\right)$ denotes the founder haplotype. The size of circle is relative to haplotype frequency. Bars indicate the number of nucleotide substitutions for GyrA (A), ParC (B) and ParE (C) sequences from fluoroquinolone resistant $P$. aeruginosa isolates recovered in Palestine. 
Table 3. Haplotype Distribution for gyrA, parC and parE genes.

\begin{tabular}{|c|c|c|c|c|c|c|}
\hline \multirow[b]{2}{*}{ Haplotype } & \multicolumn{2}{|c|}{ GyrA haplotype } & \multicolumn{2}{|c|}{ ParC haplotype } & \multicolumn{2}{|c|}{ ParE haplotype } \\
\hline & $\begin{array}{c}\text { No. of } \\
\text { haplotypes }\end{array}$ & sequence & $\begin{array}{c}\text { No. of } \\
\text { haplotypes }\end{array}$ & sequence & $\begin{array}{c}\text { No. of } \\
\text { haplotypes }\end{array}$ & sequence \\
\hline Hap-1 & 2 & $\begin{array}{l}\text { MN064784 } \\
\text { MN064787 }\end{array}$ & 1 & MN067984 & 1 & MN067995 \\
\hline Hap-2 & 2 & $\begin{array}{l}\text { MN064785, } \\
\text { MN064789 }\end{array}$ & 3 & $\begin{array}{c}\text { MN067985 MN067986 } \\
\text { MN067987 }\end{array}$ & 1 & MN067996 \\
\hline Hap-3 & 1 & MN064786 & 1 & MN067988 & 1 & MN067997 \\
\hline Hap-4 & 1 & MN064788 & 1 & MN067989 & 1 & MN067998 \\
\hline Hap-5 & 1 & MN064790 & 1 & MN067990 & 1 & MN067999 \\
\hline Hap-6 & 1 & MN064791 & 1 & MN067991 & 1 & MN068000 \\
\hline Hap-7 & 1 & MN064792 & 1 & MN067992 & 1 & MN068001 \\
\hline Hap-8 & 1 & MN064793 & 1 & MN067993 & 2 & $\begin{array}{l}\text { MN068002 } \\
\text { MN068005 }\end{array}$ \\
\hline Hap-9 & 1 & MN064794 & 1 & MN067994 & 1 & $\begin{array}{l}\text { MN068003 (indel } \\
\text { haplotype) }\end{array}$ \\
\hline Hap-10 & & & & & 1 & $\begin{array}{l}\text { MN068004 indel } \\
\text { haplotype) }\end{array}$ \\
\hline
\end{tabular}

\section{A}

Position of nucleotide change according to the reference CP034434.1

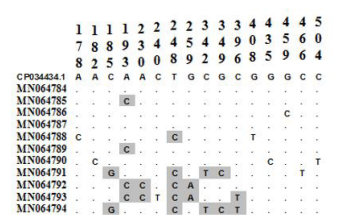

\section{B}

Position of nucleotide change according to the reference $\mathrm{CP025055.1}$

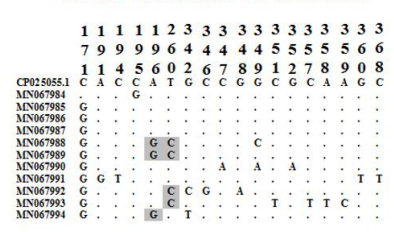

C

Position of nucleotide change according to the reference $\mathrm{CP021775.1}$

1111111111111111111111111111111111111111

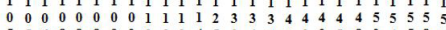

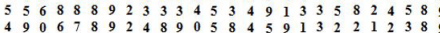

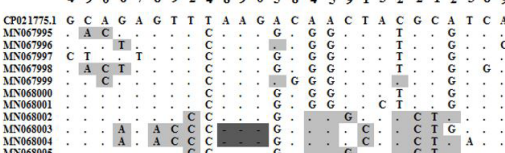

Figure 3. Nucleotide variation positions of GyrA (A), ParC (B) and ParE (C) genes among the studied fluoroquinolone resistant $P$. aeruginosa isolates according to the references from GenBank. Parsimony informative sites are shaded in light grey, while InDels are shaded in dark gray.

Table 4. Summary statistics for gyrA, parC and parE gene polymorphism in fluoroquinolone resistant $P$. aeruginosa isolates recovered in Palestine.

\begin{tabular}{lccc}
\hline \multicolumn{1}{c}{ Nucleotide diversity indexes } & & Gene & ParE \\
\cline { 2 - 4 } & GyrA & ParC & 11 \\
\hline Number of sequences & 11 & 11 & 592 \\
Number of sites & 365 & 209 & 22 \\
Variable (polymorphic) sites & 16 & 18 & 24 \\
Total number of mutations & 15 & 20 & 7 \\
Singleton variable sites & 8 & 16 & 15 \\
Parsimony informative sites & 8 & 2 & 0.982 \\
Haplotype (gene) diversity (Hd) & 0.964 & 0.945 & 0.01346 \\
Nucleotide diversity (per site), ( $\pi$ ) & 0.01225 & 0.02001 & 7.927 \\
Average number of nucleotide differences (k) & 4.473 & 4.182 & -0.14914 \\
Tajima's D & -0.80774 & -1.75596 & -2.906 \\
Fu's Fs statistic & -3.154 & -3.387 & 10 \\
Number of Haplotypes & 9 & 9 & 2 \\
Number of InDel Haplotypes & - & - & 0.00055 \\
InDel Diversity per site & - & - & 0.327 \\
InDel Haplotype Diversity & - & - & -0.10001 \\
Tajima's D for InDel Haplotypes & - & & \\
\hline
\end{tabular}


A

Position of amino acid change according to the reference ANT75468.1 $\begin{array}{llll}1 & 1 & 1 & 1\end{array}$ 66667881455 01257377536

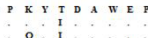

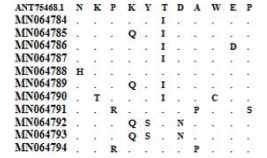

B

Position of amino acid change according to the reference AUA79862.1

$$
\begin{array}{llllll}
1 & 1 & 1 & 1 & 1
\end{array}
$$

566688111122

7456767803

425707800

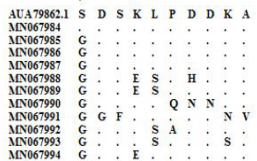

C

Position of amino acid change according to the reference ASA18488.1

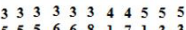

\begin{tabular}{lllllllllll}
\hline & 4 & 3 & 0 & 9 & 8 & 8 & 0 & 0
\end{tabular}

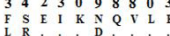

$\therefore$ D $:$ D : : : D

$\vdots$
$\vdots$
$D$

Figure 4. Amino acid variation positions of $G y r A(A), \operatorname{ParC}(\mathrm{B})$ and $\operatorname{ParE}(\mathrm{C})$ genes among the studied fluoroquinolone resistant $P$. aeruginosa isolates according to the references from GenBank.

\section{Discussion}

Fluoroquinolones are an important class of antimicrobial agents for the treatment of $P$. aeruginosa infections. The emergence of acquired resistance in $P$. aeruginosa is mainly due to mutations in the genes of DNA gyrase and topoisomerase IV. Several studies are suggested the correlation between the number of mutations in the genes of DNA gyrase and topoisomerase IV and the level of fluoroquinolone resistance (Lee et al., 2005; Nouri et al., 2016). The association was established between the wide use of fluoroquinolones in community practice and the frequency of bacteria resistance to these antimicrobial agents in hospitalized patients (MacDougall et al., 2005). This association between an inappropriate use of fluoroquinolones, the resistance selection to this class of antimicrobial agents, and the higher risk associated with treatment failure makes it mandatory to encourage a well-reasoned and appropriate use of these agents (Scheld, 2003).

This study highlights some of the phenotypic characteristics and genetic variations undergone by a fluoroquinolone resistant $P$. aeruginosa pathogen. These strains showed high MIC level for fluoroquinolones (ciprofloxacin and norfloxacin), $\beta$-lactamase producers, carried type III secretion exotoxin-encoding genes, most of them had integrase I gene and had high level of mutations in QRDR regions in gyrA, parC and parE genes. All these factors may play an important role in the invasiveness of these strains and make them difficult to treat. The identification of $\beta$-lactamase genes and other virulence genes and the dissemination of these strains in different Medical centers, indicate the need for a more strict application of infection control measures in Medical centers in the North West Bank-Palestine that aim to reduce expense and damage caused by $P$. aeruginosa infections.

Results of this study showed high level of fluoroquinolone resistance in these strains and this could be correlated with number of mutations in QRDR regions in gyrA, parC and parE sequences (Reinhardt et al., 2002; Lee et al., 2005; Nouri et al., 2016). Mechanisms of resistance to fluoroquinolones include two groups of mutation and acquisition of resistance-conferring genes. Resistance mutations in one or both of the two drug target enzymes, DNA gyrase and DNA topoisomerase IV, are commonly in a localized domain of the GyrA and ParE subunits of the respective enzymes and reduce drug binding to the enzymeDNA complex. Other mechanism due to mutations occur in regulatory genes that control the expression of efflux pumps located in the bacterial cell membrane. Both types of these mutations can accumulate with selection pressure and produce highly resistant strains. The magnitude of resistance caused by single amino acid changes in the subunits of gyrase or topoisomerase IV varies by bacterial species and by quinolone (Hooper and Jacoby, 2015). Successive mutations in both gyrase and topoisomerase IV enzymes have been shown to provide rising levels of quinolone resistance. In many species, high-level quinolone resistance is often associated with mutations in both gyrase and topoisomerase IV (Schmitz et al., 1998).

The genetic variation of a species is distributed both within populations, expressed as differences between individuals and between populations, expressed as differences in the presence and frequency of alleles (Garg and Mishra, 2018). In this study, analyses of the gyrA, parC and parE sequences were found to be polymorphic with high haplotype diversity (Hd) (0.945-0.982) and low nucleotide diversity (0.01225-0.02001). The number of haplotypes were 9 for each gyrA and parE genes and 10 haplotypes for parC gene. The black nodes (Hap) are the DNA sequences for these genes which represent the haplotypes, while light black nodes are median vectors $(\mathrm{mv})$, which are considered the hypothesized (often ancestral) sequences for our sequences. These are required to connect existing sequences within the network with maximum parsimony. Such gene flow in these Palestinian fluoroquinolone resistant $P$. aeruginosa haplotypes can potentially reduce genetic differentiation. The median joining network of gyrA, parC and parE sequences revealed "star-like" networks, suggesting population expansion haplotypes from a main founder haplotype. Along with the negative values of the neutrality tests Tajima's D and Fu's Fs statistic tests, further supported the hypothesis of population expansion of fluoroquinolone resistant $P$. aeruginosa in Palestine. The low nucleotide diversity is most likely a result due to different factors even had many haplotypes, this means that these haplotypes had very similarity between them. In addition, parsimony informative sites may play a role in low nucleotide diversity.

\section{Conclusions}

Fluoroquinolones used to treat infections due to first-step mutant strains may lead to the selection of 
another mutation, which in turn could induce high-level of resistance to fluoroquinolones. Identifying first step mutants is important to adjust treatment and ensure the epidemiological monitoring of fluoroquinolone resistance.

Palestinian fluoroquinolone resistant $P$. aeruginosa strains showed high MIC level for fluoroquinolones, $\beta$-lactamase producers, carried type III secretion exotoxinencoding genes, most of them had integrase I gene and had high level of mutations in QRDR regions in gyrA, parC and parE genes. All these factors may play an important role in the invasiveness of these strains and making the treatment of infections not easy. Identification and dissemination of these strains in different medical centers, indicate the need for adoption of a more strict application of infection control measures in Medical centers in the North West Bank-Palestine, that aim to reduce expense and damage caused by $P$. aeruginosa infections. Molecular analyses showed that Palestinian fluoroquinolone resistant $P$. aeruginosa haplotypes are not genetically differentiated and more mutations may exist in these strains. The tested number of isolates in the current study was very small, hence, future testing of a larger number of fluoroquinolone resistant $P$. aeruginosa isolates is required for a more clear picture about haplotype diversity, nucleotide diversity and genetic differentiation.

\section{Acknowledgements}

The authors thank Dr. Nael Abu Hasan, Department of Biology and Biotechnology, An-Najah National UniversityPalestine, for language revision.

\section{References}

ADWAN, G., ADWAN, K., JARRAR, N., SALAMA, Y. and BARAKAT, A., 2013. Prevalence of seg, seh and sei genes among clinical and nasal Staphylococcus aureus isolates. British Microbiology Research Journal, vol. 3, no. 2, pp. 139-149. http://dx.doi. org/10.9734/BMRJ/2013/2913.

AGNELLO, M. and WONG-BERINGER, A., 2012. Differentiation in quinolone resistance by virulence genotype in Pseudomonas aeruginosa. Public Library of Science, vol. 7, no. 8, e42973. http:// dx.doi.org/10.1371/journal.pone.0042973.

AJAYI, T., ALLMOND, L.R., SAWA, T. and WIENER-KRONISH, J.P., 2003. Single-nucleotide-polymorphism mapping of the Pseudomonas aeruginosa type III secretion toxins for development of a diagnostic multiplex PCR system. Journal of Clinical Microbiology, vol. 41, no. 8, pp. 3526-3531. http:// dx.doi.org/10.1128/JCM.41.8.3526-3531.2003. PMid:12904350.

BANDELT, H.J., FORSTER, P. and ROHL, A., 1999. Median-joining networks for inferring intraspecific phylogenies. Molecular Biology and Evolution, vol. 16, no. 1, pp. 37-48. http://dx.doi. org/10.1093/oxfordjournals.molbev.a026036. PMid:10331250.

BOYD, D.A., TYLER, S., CHRISTIANSON, S., MCGEER, A., MULLER, M.P., WILLEY, B.M., BRYCE, E., GARDAM, M., NORDMANN, P. and MULVEY, M.R., 2004. Complete nucleotide sequence of a 92-kilobase plasmid harbouring the CTX-M-15 extended spectrum beta-lactamase involved in an outbreak in longterm-care facilities in Toronto, Canada. Antimicrobial Agents and Chemotherapy, vol. 48, no. 10, pp. 3758-3764. http://dx.doi. org/10.1128/AAC.48.10.3758-3764.2004. PMid:15388431.
CLINICAL AND LABORATORY STANDARDS INSTITUTE - CLSI, 2016. Performance standards for antimicrobial susceptibility testing. 26th ed. Wayne: CLSI. CLSI supplement. M100S.

DALHOFF, A., 2012. Global fluoroquinolone resistance epidemiologyand implications for clinical use. Interdisciplinary Perspectives on Infectious Diseases, vol. 2012, pp. 1-37. http:// dx.doi.org/10.1155/2012/976273. PMid:23097666.

ELLINGTON, M.J., KISTLER, J., LIVERMORE, D.M. and WOODFORD, N., 2007. Multiplex PCR for rapid detection of genes encoding acquired metallo- $\beta$-lactamases. The Journal of Antimicrobial Chemotherapy, vol. 59, no. 2, pp. 321-322. http://dx.doi. org/10.1093/jac/dkl481. PMid:17185300.

FRANKLIN, C., LIOLIOS, L. and PELEG, A.Y., 2006. Phenotypic detection of carbapenem-susceptible metallo-lactamaseproducing gram-negative Bacilli in the clinical laboratory. Journal of Clinical Microbiology, vol. 44, no. 9, pp. 3139-3144. http://dx.doi.org/10.1128/JCM.00879-06. PMid:16954239.

GARG, R.K. and MISHRA, V., 2018. Molecular insights into the genetic and haplotype diversity among four populations of Catla catla from Madhya Pradesh revealed through mtDNA cyto $b$ gene sequences. Journal, Genetic Engineering \& Biotechnology, vol. 16, no. 1, pp. 169-174. http://dx.doi.org/10.1016/j.jgeb.2017.11.003. PMid:30647719.

GIAMARELLOU, H. and ANTONIADOU, A., 2001. Antipseudomonal antibiotics. The Medical Clinics of North America, vol. 85, no. 1, pp. 19-42. http://dx.doi.org/10.1016/S0025-7125(05)70303-5. PMid:11190351.

HOOPER, D.C. and JACOBY, G.A., 2015. Mechanisms of drug resistance: quinolone resistance. Annals of the New York Academy of Sciences, vol. 1354, no. 1, pp. 12-31. http://dx.doi.org/10.1111/ nyas.12830. PMID: 26190223.

IBRAHIM, M.E., BILAL, N.E., MAGZOUB, M.A. and HAMID, M.E., 2013. Prevalence of Extended-spectrum $\beta$-lactamases-producing Escherichia coli from hospitals in Khartoum State, Sudan. Oman Medical Journal, vol. 28, no. 2, pp. 116-120. http://dx.doi. org/10.5001/omj.2013.30. PMid:23599880.

KIM, J., JEON, S., RHIE, H., LEE, B., PARK, M., LEE, H., LEE, J. and KIM, S., 2009. Rapid detection of extended spectrum $\beta$-lactamase (ESBL) for Enterobacteriaceae by use of a multiplex PCR-based method. Infection E Chemotherapy, vol. 41, no. 3, pp. 181-184. http://dx.doi.org/10.3947/ic.2009.41.3.181.

KOBAYASHI, H., ISOZAKI, M., FUKUDA, T., ANZAI, Y. and KATO, F., 2013. Surveillance of fluoroquinolone-resistant clinical isolates of Pseudomonas aeruginosa. Open Journal of Medical Microbiology, vol. 3, no. 2, pp. 144-150. http://dx.doi.org/10.4236/ ojmm.2013.32022.

LEE, J.K., LEE, Y.S., PARK, Y.K. and KIM, B.S., 2005. Alterations in the GyrA and GyrB subunits of topoisomerase II and the ParC and ParE subunits of topoisomerase IV in ciprofloxacin-resistant clinical isolates of Pseudomonas aeruginosa. International Journal of Antimicrobial Agents, vol. 25, no. 4, pp. 290-295. http:// dx.doi.org/10.1016/j.jiantimicag.2004.11.012. PMid:15784307.

LEE, K., LEE, W.G., UH, Y., HA, G.Y., CHO, J., CHONG, Y. and KOREAN NATIONWIDE SURVEILLANCE OF ANTIMICROBIAL RESISTANCE GROUP, 2003. VIM- and IMP-type metallo-beta-lactamaseproducing Pseudomonas spp. and Acinetobacter spp. in Korean hospitals. Emerging Infectious Diseases, vol. 9, no. 7, pp. 868-871. http://dx.doi.org/10.3201/eid0907.030012. PMid:12890331.

LIBRADO, P. and ROZAS, J., 2009. DnaSP v5: a software for comprehensive analysis of DNA polymorphism data. Bioinformatics, vol. 25, no. 11, pp. 1451-1452. http://dx.doi. org/10.1093/bioinformatics/btp187. PMID: 19346325. 
LIHUA, L., JIANHUI, W., JIALIN, Y., YAYIN, L. and GUANXIN, L., 2013. Effects of allicin on the formation of Pseudomonas aeruginosa biofinm and the production of quorum-sensing controlled virulence factors. Polish Journal of Microbiology, vol. 62, no. 3, pp. 243-251. http://dx.doi.org/10.33073/pjm-2013-032. PMid:24459829.

LISTER, P.D., WOLTER, D.J. and HANSON, N.D., 2009. Antibacterialresistant Pseudomonas aeruginosa: clinical impact and complex regulation of chromosomally encoded resistance mechanisms. Clinical Microbiology Reviews, vol. 22, no. 4, pp. 582-610. http:// dx.doi.org/10.1128/CMR.00040-09. PMID: 19822890.

LLANES, C., KÖHLER, T., PATRY, I., DEHECQ B., VAN DELDEN, C. and PLÉSIAT, P., 2011. Role of the efflux system MexEF-OprN in low level resistance of Pseudomonas aeruginosa to ciprofloxacin. Antimicrobial Agents and Chemotherapy, vol. 55, no. 12, pp. 5676 5684. http://dx.doi.org/10.1128/AAC.00101-11. PMID: 21911574.

MACDOUGALL, C., POWELL, J.P., JOHNSON, C.K., EDMOND, M.B. and POLK, R.E., 2005. Hospitaland community fluoroquinolone use and resistance in Staphylococcus aureus and Escherichia coli in 17 US hospitals. Clinical Infectious Diseases, vol. 41, no. 4, pp. 435-440. http://dx.doi.org/10.1086/432056. PMid:16028149.

MANSOURI, S., NEYESTANAKI, D.K., SHOKOOHI, M., HALIMI, S., BEIGVERDI, R., REZAGHOLEZADEH, F. and HASHEMI, A., 2014. Characterization of AmpC, CTX-M and MBLs types of $\beta$-lactamases in clinical isolates of Klebsiella pneumoniae and Escherichia coli producing extended spectrum $\beta$-lactamases in Kerman, Iran. Jundishapur Journal of Microbiology, vol. 7, no. 2, e8756. http://dx.doi.org/10.5812/jjm.8756. PMID: 25147671.

MONSTEIN, H.J., OSTHOLM-BALKHED, A., NILSSON, M.V., NILSSON, M., DORNBUSCH, K. and NILSSON, L., 2007. Multiplex PCR amplification assay for the detection of blaSHV, blaTEM and blaCTXM genes in Enterobacteriaceae. APMIS. Acta Pathologica, Microbiologica, et Immunologica Scandinavica, vol. 115, no. 12, pp. 1400-1408. http://dx.doi.org/10.1111/j.1600-0463.2007.00722.x. PMid:18184411.

NOURI, R., AHANGARZADEH REZAEE, M., HASANI, A., AGHAZADEH, M. and ASGHARZADEH, M., 2016. The role of gyrA and parC mutations in fluoroquinolones-resistant Pseudomonas aeruginosa isolates from Iran. Brazilian Journal of Microbiology, vol. 47, no. 4, pp. 925-930. http://dx.doi.org/10.1016/j.bjm.2016.07.016. PMid:27522930.

PATERSON, D.L., HUJER, K.M., HUJER, A.M., YEISER, B., BONOMO, M.D., RICE, L.B., BONOMO, R.A., and INTERNATIONAL KLEBSIELLA STUDY GROUP, 2003. Extended spectrum betalactamases in Klebsiella pneumoniae bloodstream isolates from seven countries: dominance and widespread prevalence of SHVand CTX-M type beta-lactamases. Antimicrobial Agents and Chemotherapy, vol. 47, no. 11, pp. 3554-3560. http://dx.doi. org/10.1128/AAC.47.11.3554-3560.2003. PMid:14576117.

PEREZ, L.R.R., LIMBERGER, M.F., COSTI, R., DIAS, C.A.G. and BARTH, A.L., 2014. Evaluation of tests to predict metallo- $\beta$-lactamase in cysticfibrosis (CF) and non-(CF) Pseudomonas. Brazilian Journal of Microbiology, vol. 45, no. 3, pp. 835-839. http://dx.doi. org/10.1590/S1517-83822014000300011. PMid:25477915.

PEREZ-PEREZ, F.J. and HANSON, N.D., 2002. Detection of plasmidmediated AmpC beta-lactamase genes in clinical isolates by using multiplex PCR. Journal of Clinical Microbiology, vol. 40, no. 6, pp. 2153-2162. http://dx.doi.org/10.1128/JCM.40.6.21532162.2002. PMid:12037080.

POIREL, L., WALSH, T.R., CUVILLIER, V. and NORDMANN, P., 2011. Multiplex PCR for detection of acquired carbapenemase genes. Diagnostic Microbiology and Infectious Disease, vol. 70, no. 1, pp.
119-123. http://dx.doi.org/10.1016/j.diagmicrobio.2010.12.002. PMid:21398074.

REINHARDT, A.K., BÉBÉAR, C.M., KOBISCH, M., KEMPF, I. and GAUTIER-BOUCHARDON, A.V., 2002. Characterization of mutations in DNA gyrase and topoisomerase IV Involved in quinolone resistance of Mycoplasma gallisepticum mutants obtained in vitro. Antimicrobial Agents and Chemotherapy, vol. 46, no. 2, pp. 590-593. http://dx.doi.org/10.1128/AAC.46.2.590593.2002. PMid: 11796386

SCHELD, W.M., 2003. Maintaining fluoroquinolone class efficacy: review of influencing factors. Emerging Infectious Diseases, vol. 9, no. 1, pp. 1-9. http://dx.doi.org/10.3201/eid0901.020277. PMid: 12533274.

SCHMITZ, F.J., JONES, M.E., HOFMANN, B., HANSEN, B., SCHEURING, S., LÜCKEFAHR, M., FLUIT, A., VERHOEF, J., HADDING, U., HEINZ, H.P. and KÖHRER, K., 1998. Characterization of grlA grlB gyrA and gyrB mutations in 116 unrelated isolates of Staphylococcus aureus and effects of mutations on ciprofloxacin MIC. Antimicrobial Agents and Chemotherapy, vol. 42, no. 5, pp. 1249-1252. http:// dx.doi.org/10.1128/AAC.42.5.1249. PMid:9593159.

SEKIGUCHI, J., ASAGI, T., MIYOSHI-AKIYAMA, T., FUJINO, T., KOBAYASHI, I., MORITA, K., KIKUCHI, T., KURATSUJI, T. and KIRIKAE, T., 2005. Multidrug-resistant Pseudomonas aeruginosa strain that caused an outbreak in a neurosurgery ward and its aac(6 )-Iae gene cassette encoding a novel aminoglycoside acetyltransferase. Antimicrobial Agents and Chemotherapy, vol. 49, no. 9, pp. 3734-3742. http://dx.doi.org/10.1128/AAC.49.9.37343742.2005. PMid:16127047.

SHIBATA, N., DOI, Y., YAMANE, K., YAGI, T., KUROKAWA, H., SHIBAYAMA, K., KATO, H., KAI, K. and ARAKAWA, Y., 2003. PCR typing of genetic determinants for metallo-beta-lactamases and integrases carried by Gram-negative bacteria isolated in Japan, with focus on the class 3 integron. Journal of Clinical Microbiology, vol. 41, no. 12, pp. 5407-5413. http://dx.doi. org/10.1128/JCM.41.12.5407-5413.2003. PMid:14662918.

SPECIALE, A., MUSUMECI, R., BLANDINO, G., CACCAMO, F., SIRACUSA, V. and RENIS, M., 2000. Molecular mechanisms of resistance in Pseudomonas aeruginosa to fluoroquinolones. International Journal of Antimicrobial Agents, vol. 14, no. 2, pp. 151-156. http:// dx.doi.org/10.1016/s0924-8579(99)00139-9. PMID: 10720806.

TAMURA, K., STECHER, G., PETERSON, D., ALAN FILIPSKI, A. and KUMAR, S., 2013. MEGA6: Molecular evolutionary genetics analysis version 6.0. Molecular Biology and Evolution, vol. 30, no. 12, pp. 2725-2729. http://dx.doi.org/10.1093/molbev/ mst197. PMID: 24132122.

TEJEDOR, M.T., MARTÍN, J.L., NAVIA, M., FREIXES, J. and VILA, J., 2003. Mechanisms of fluoroquinolone resistance in Pseudomonas aeruginosa isolates from canine infections. Veterinary Microbiology, vol. 94, no. 4, pp. 295-301. http:// dx.doi.org/10.1016/s0378-1135(03)00129-9. PMID: 12829383.

WYDMUCH, Z., SKOWRONEK-CIOLEK, O., CHOLEWA, K., MAZUREK, U., PACHA, J., KEPA, M., IDZIK, D. and WOJTYCZKA, R.D., 2005. GyrA mutations in ciprofloxacin-resistant clinical isolates of Pseudomonas aeruginosa in a Silesian Hospital in Poland. Polish Journal of Microbiology, vol. 54, no. 3, pp. 201-206. PMid:16450835.

YONG, D., LEE, K., YUM, J.H., SHIN, H.B., ROSSOLINI, G.M. and CHONG, Y., 2002. Imipenem-EDTA disk method for differentiation of metallo- $\beta$-lactamase-producing clinical isolates of Pseudomonas spp. and Acinetobacter spp. Journal Clinical of Microbiology, vol. 40, no. 10, pp. 3798-3801. http://dx.doi.org/10.1128/ jcm.40.10.3798-3801.2002. PMID: 12354884. 